\title{
COVID-19, Ghanaian Household Consumption, Where to from Here?
}

\author{
Robert Brenya $^{1 *}$, Jing Zhu', Derrick Acquanah Cudjoe², Michael Boakye Yiadom ${ }^{3}$, \\ Deborah Ofosu ${ }^{4}$
}

${ }^{1}$ College of Economics and Management, Nanjing Agricultural University, Nanjing, China

${ }^{2}$ School of Economics and Management, Southeast University, Nanjing, China

${ }^{3}$ Department of Marketing, Nelson Mandela University, Port Elizabeth, South Africa

${ }^{4}$ School of Management Science and Engineering, Nanjing University of Information Science and Technology, Nanjing, China

Email: ^brenyarobert@yahoo.com

How to cite this paper: Brenya, R., Zhu, J., Cudjoe, D. A., Yiadom, M. B., \& Ofosu, D. (2020). COVID-19, Ghanaian Household Consumption, Where to from Here? Open Journal of Business and Management, 8 , 2460-2471.

https://doi.org/10.4236/ojbm.2020.86152

Received: October 1, 2020

Accepted: November 13, 2020

Published: November 16, 2020

Copyright $\odot 2020$ by author(s) and Scientific Research Publishing Inc. This work is licensed under the Creative Commons Attribution International License (CC BY 4.0).

http://creativecommons.org/licenses/by/4.0/

\begin{abstract}
No one likes a stressful living. Unfortunately, that is all COVID-19 brings to humanity. The impact of stringent restrictions due to COVID-19 has led to the overwhelming human tragedy in every region of the world including Ghana. The study explores what next for the Ghanaian household consumption after the pandemic is over in the country, especially the measures the individual stakeholders are going to lay down for the recovery of the economic, reliable livelihood with enough household food consumption and prevention of future pandemics in the region. The data source was from the Ghana Statistical Service, Epidemic-Sats.Com, Knoema.com, and the United Nations (FAO and WHO). The study suggests potential resolutions for post-COVID-19 and/or effective channels for the Ghanaian government and the other institutions as to what to do to sustain the household consumption from here.
\end{abstract}

\section{Keywords}

COVID-19, Consumption, Ghana, Household, Lockdown

\section{Background}

Ghana is a West African nation well-known for democratic governance and stability with a strong advocate for poverty and hunger reduction until the impact of COVID-19. The Ghanaian agriculture is one of the promoters of the economy that is affected by the COVID-19 pandemic. This is a similar impact happening across the world. Agriculture and food were the least affected sector in the Canadian economy (Larue, 2020). However, this is not the same in other regions especially the developing countries, where Coronavirus has put everything to a 
standstill. The Novel Corona Virus (COVID-19) originated from a live animal being sold at a wet market ( $\mathrm{Li}$ et al., 2020). The virus spread through the world through air travel to the wealthy countries but momentarily entered the low-income neighboring regions (William, 2020). COVID-19, since its origination has been the global pandemic matched with worrisome issues to policymakers. It is a contagious virus from the Corona family with similar symptoms such as the Severe Acute Respiratory Syndrome (SARS-CoV) and Middle East Respiratory Syndrome (MERS-CoV). The contracted person suffers greatly with respiration problems with an indication of fever, cough, difficulty in breathing (WHO, 2020). The mode of transmission is getting in contact with an object's surface that has the virus on it and taking it to your eyes, nose, and mouth, because the virus can survive on certain surfaces for some hours before it dies (WHO, 2020). Another mode of transfer is through direct contact with an infected person (both asymptomatic and symptomatic), especially when the person coughs, sneezes, and/or talks towards you (Gray, 2020; WHO, 2020). COVID-19 spread at a distressing speed (FAO. 2020a), paralleled with a financial crush, country's economic uncertainties, and loss of human lives. In order to salvage the situation, nations authorities had limited choice but to bring strict policies, such as physical distancing, lockdowns, compulsory wearing masks, sterilizations using soaps, sanitizers and the like to mitigate the spread (FAO. 2020b). The World Bank (World Bank, 2020a) postulated: countries ought to control the spread of the virus else risk imminent financial recession. This has presented countless challenges for policymakers, farmers, marketers, agricultural sectors, institutions, and particularly the household food consumption.

\section{Introduction}

World Health Organization (WHO), 2020 defines Corona disease (COVID-19) as an infectious disease caused by a newly discovered coronavirus, and people with underlying medical problems are more likely to develop serious illness. By March 2020, all the West African countries including, Ghana have informed the WHO of COVID-19 cases and the measures in place for containment (FAO. 2020e). The region's economy has been crippled since the appearance of COVID-19, the catastrophic nature of this virus has precipitated food insecurity issues in Africa (Senahoun, 2020) especially in Ghana where consumption has become problematic. Agricultural productivity has been the community priority as to humanity's sustenance compared to the growing population. B\&FT Online, (B\&FT Online, 2020), asserted, 54\% of Ghana's GDP emanates from agriculture with the provision of $90 \%$ of the country's food needs. The effect of the sudden necessity of food at home due to lockdowns and prevention of cross-border trading put household food consumption risk (William, 2020). Farmers apart from the health workers are also in line when it comes to the fighting of COVID-19 pandemic, they must let go of their fear of contracting the disease outside and go to their rural farms to find foods for the households, most far- 
mers are able to produce more for sustainability (B\&FT Online, 2020), they are the silent heroes and heroines whose work are more crucial now than ever (Leila, 2020). That notwithstanding, the graving impact of COVID-19 in the urban areas make farmers worry about increased loss of food especially perishable ones (FAO, 2020f) in the midst of the pandemic. Furthermore, the mitigating practices such as lockdowns, quarantines, border closures, etc. are the sustainable panaceas most governments are implementing. This has had an enormous negative impact on household consumption and farming activities such as food demand and supply chains, the farm produces, fertilizers, and the entire agricultural sectors as a whole. This study looks into the aftermaths of COVID-19 pandemic for the Ghanaian households' consumption. And ask a question; Where to from here for the household consumption after the pandemic? The paper further contains the Literature Review which is next after the Introduction, Procedural Notes, and Interpretation with no empirical model, followed by Discussion and Conclusion.

\section{Literature Review}

History teaches us about infectious pandemics that destroyed mankind decades ago. Novel Coronavirus also known as COVID-19 is one of the airborne viruses from the Corona family which spread directly and indirectly, especially when an infected person sneezed or coughed into the air and uninfected person breathes in the droplets. An unprecedented experience paralleled with rampant loss of lives, economic crunch, food crisis, surges in unemployment (FAO, 2020f) is what COVID-19 brings to mankind. The effect of this pandemic will be felt in a long time even after a vaccine is developed (FAO, 2020h). Money obtain annually between US $\$ 378$ million and US $\$ 981$ million from the Ghana export of cash crops have been greatly undercut (Gakpo, 2020) due to the close-downs of processing factories across the countries. According to the International Monetary Fund (IMF), 2020, the global economy is foretold to be 5\% decline in 2020, worse than the 2008/9 recession (Laborde et al., 2020). As a result, the governments are unsure as to the gravity of COVID-19 impact on food supply (William, 2020) and demand (FAO, 2020c). More so, some governments have initiated hygienic amenities along the road networks, making it available to passersby, others have also approved exemptions to agricultural workers to safeguard labor availability (European Commission, 2020; FAO, 2020h). The pandemic has already jeopardized governments supported programs to agricultural investment, putting the farmers' income at risk (FAO, 2020h), pushing 150 million people to extreme poverty (Laborde et al., 2020) based on the model by International Food Policy Research Institute (IFPRI) using the financial crisis as a proxy. Furthermore, school children access to systematic school feeding and nutrition service might be ceased because of the nationwide and localized lockdowns (WFP, FAO \& UNICEF, 2020). FAO (FAO, 2020g), asserted, we cannot wait until the health predicament is resolved. Without vaccines, the containment 
of COVID-19 continues to linger fear into the people alongside disrupting the bio-economic supplies which help enhance production. The Ghanaian agricultural sector has restrained workers from farming, leading to scarce of staple food supply and consumption, the decay of perishable fruits and vegetables and the like. Furthermore, supply chain problems have led to panic buying with an amount on average to $20 \%$ and upwards for grain such as rice, vegetables, and the like (Awuah, 2020). The institutions cautioned that, countries trade-related prevention measures should not disturb the food supply chain (WHO, FAO, and WTO, 2020). The Food and Agricultural Organization (FAO, 2020d), enunciated that, the country's turmoil has exacerbated farms and Agri enterprises' ability to consistently supply food to consumers due to physical distancing. Food and Agriculture Organization said, 250 million Africans are experiencing extremely food insure. The agricultural sector acknowledges, the country is unable to harvest adequate food to meet the demand in the midst of this pandemic, resulting in food insecurity (B\&FT Online, 2020). John-Rye Adade, 2020 postulated, food insecurity in various regions of Ghana is higher during rainy seasons, and this pandemic season tied with economic uncertainties, lockdowns, job losses, etc. has made it worse. Furthermore, the pandemic has brought logistical disruption, making it difficult for farmers to supply the food they produced to the markets (FAO, 2020c). Especially, the break in transportation linkages whereby farmers are unable to supply their farm products to grocery stores, bars, and restaurants to the urban sectors due to COVID-19 (FAO, 2020e). Ghanaian farmers' fear of lack of liquidity might reduce the demand for agricultural input leading to low household consumption (FAO, 2020h). FAO besiege the leaders in every nation to implement the holistic approach to solve food loss, enhance feeding and waste reduction whiles controlling, in order to improve easy access to food during this season (FAO, 2020f). His Excellency Nana Addo Dankwa Akufo-Addo, the President of the Republic of Ghana, spelled out measures that has been put in place to control the global pandemic in the country, and further assist the frontline health workers, farmers, etc. (Adade, 2020). With $\$ 40$ million to the distribution of food and meal packages to over 400,000 individuals affected by the restriction (Gakpo, 2020). Gakpo Opoku Joseph (Gakpo, 2020); further said an equal amount has also been allocated to Ghana National Buffer Stock Company which is under the Ministry of Agriculture for contingent purposes during the lockdowns. Nearly $70 \%$ out of the 5 million farming households are smallholder farmers in the country (B\&FT Online, 2020). This has enabled Peasant Farmers Association of Ghana (PFAG) in collaboration with the Health Directorate to educate farmers on household food consumption and safety protocols of World Health Organization (B\&FT Online, 2020).

\section{Procedural Notes and Interpretation}

The data source of this study was from Ghana Statistical Service (GSS), Epidemic-Sats.Com, Knoema.com, and United Nations (FAO and WHO). It is based on 
the most recent reported cases of COVID-19 in Ghana since the inception around March up to late of August, 2020. The study does not discount the fact, the accuracy of the exact number cases will differ as the days go by with infections. However, data reported by the institutes above should be considered the most up to date and accurate. As at the end of August, 2020 on the Epidemic-Sats.Com platform (Figure 1), the total number of active and infected is 44298 infected with $97 \%$ recovered rate and $0.6 \%$ deaths.

The detail calculation in Equations (1) and (2) below:

Let; $A=$ total number of infected in the region

$B=$ total number of recovered in the region

$C=$ total number of deaths in the region

$$
\begin{gathered}
\% \text { of Recovered }=\frac{B}{A}=\frac{42963}{44298} \times 100=97 \% \\
\% \text { of Deaths }=\frac{C}{A}=\frac{276}{44298} \times 100=0.6 \%
\end{gathered}
$$

Furthermore, Table 1 indicates the total cumulative COVID-19 cases for the World, Africa and Ghana.

Moreover, the survey conducted by the Ghana Statistical Service (GSS, 2020), the Government Statistician, Professor Samuel Annim enunciated, 22 million Ghanaian household income has been affected since March, $16^{\text {th }} 2020$ (GSS, 2020). According to GSS, 2020; 3.4\% estimating 1 million individual's labor has been deferred because of the restrictions with $9 \%$ relying on food resources from

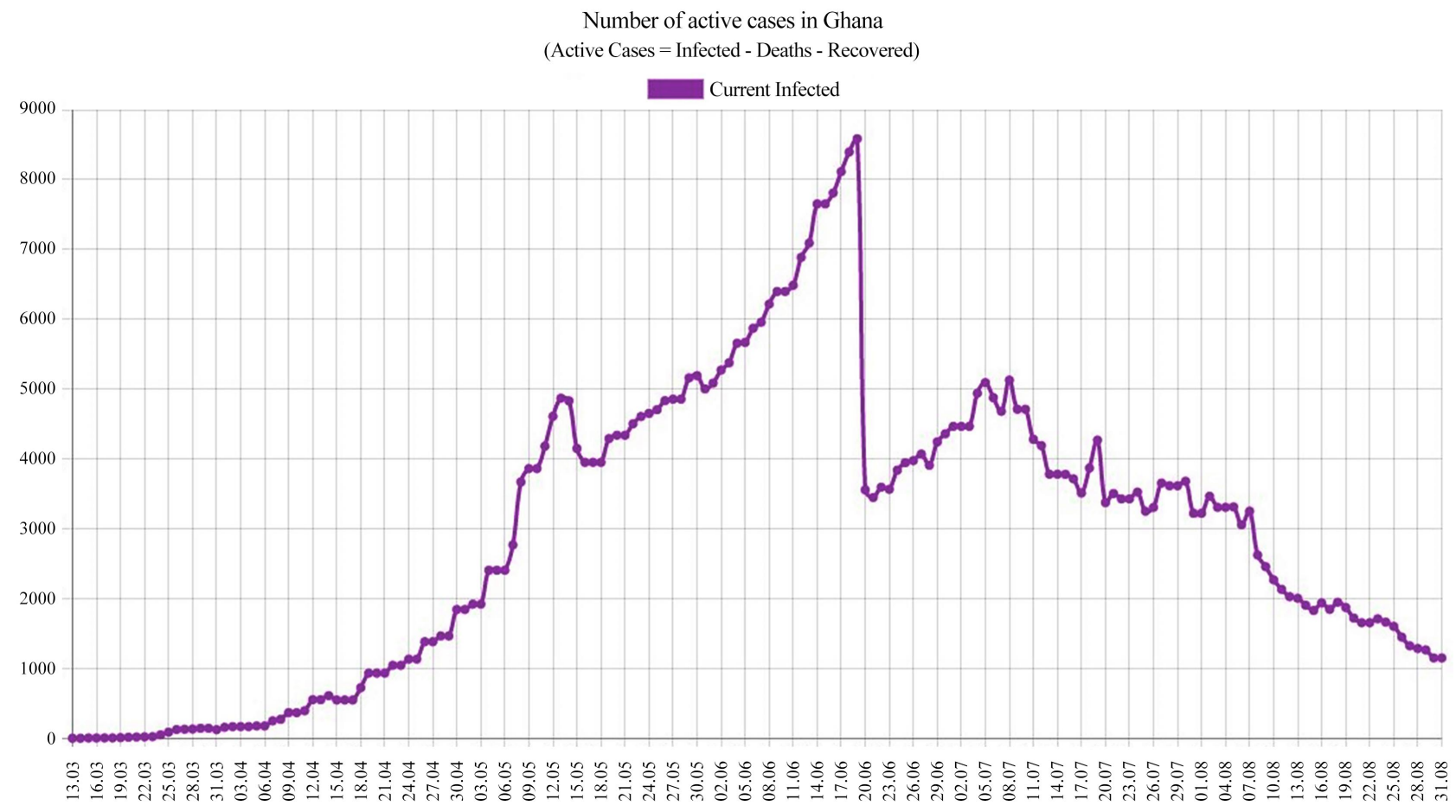

Figure 1. Number of active cases in Ghana, number of infected, deaths and recovered in Ghana. Source: Epidemic-Sats.Com. 
Table 1. Covid-19 cases as at August $30^{\text {th }}, 2020$.

\begin{tabular}{ccccc}
\hline Covid-19 & $\begin{array}{c}\text { Cases - Cumulative } \\
\text { Total }\end{array}$ & $\begin{array}{c}\text { Cases-Newly } \\
\text { Reported in Last 24 } \\
\text { Hours }\end{array}$ & $\begin{array}{c}\text { Deaths-Cumulative } \\
\text { Total }\end{array}$ & $\begin{array}{c}\text { Deaths-Newly } \\
\text { Reported in Last 24 } \\
\text { Hours }\end{array}$ \\
\hline World & $24,854,140$ & 265,888 & 938,924 & 5361 \\
Africa & $1,175,248$ & 6957 & 28,268 & 303 \\
Ghana & 43,949 & 108 & 270 & \\
\hline
\end{tabular}

Source: WHO. (https://www.who.int/emergencies/diseases/novel-coronavirus-2019).

others. Meanwhile, Figure $2 \&$ Figure 3 gives a graphical indication of household school children who continue to avoid studies while at home, $35 \%$ and $28 \%$ representing Junior High School (JHS with primary included) and Senior High School (SHS) respectively, even though $96.6 \%$ are willing to go back to school when restrictions are lifted (GSS, 2020).

With $77.4 \%$ dropped of household income leading to $52.1 \%$, which is greater than half of the household are forced to ration food consumption. According to the government statistician, students age, ranging from 6 to 14 years representing more than 57\% still enjoyed the School Feeding Program weeks before while schools remain closed (GSS, 2020). The Global Economic Prospects, looks into the movements of the world economy and how it affects Ghana using three-year forecasts for major macroeconomic indicators with a decline (World bank, 2020b). Further stated, the impact of this pandemic has contributed to the deterioration, however, there is a positive sign of the rate of fiscal growth, national income, consumption price levels and the like after the pandemic season. The agricultural contribution to Ghana's GDP cannot be underestimated and has been doing good until this pandemic. The economic value of goods and services have been immensely affected due to the COVID-19, there is doubt as to when and how economic restrictions will be wholly lowered in countries (Larue, 2020) and the impact on the GDP of the previous year was encouraging until it started shrinking (using the Real GDP in calculating Figure 4) in the midst of the pandemic since finished goods and services produced in the country within this period are all on halt.

From the pictorial representation of Figure 4, the line curve gradually going up from the year 2020 due to the government spending to support the people, petty income as a result of slight easing of the lockdowns to enable commerce, and the production of other essentials needed to fight the pandemic. As it is relevant to try and improve the economy, Ken Ofori Atta, the Finance Minister of Ghana, asserted that these shortages of goods and services will cost the country US $\$ 1.9$ billion representing 2.5\% of the country's Gross Domestic Product (GDP) (Gakpo, 2020), impeding on economy development. Though, both the IMF, 2020 and the World Bank has made provision to alleviate most of the poor countries from the financial constraints and other domestic production for post COVID-19 (World Bank, 2020a), there is small hope as to its significance. 


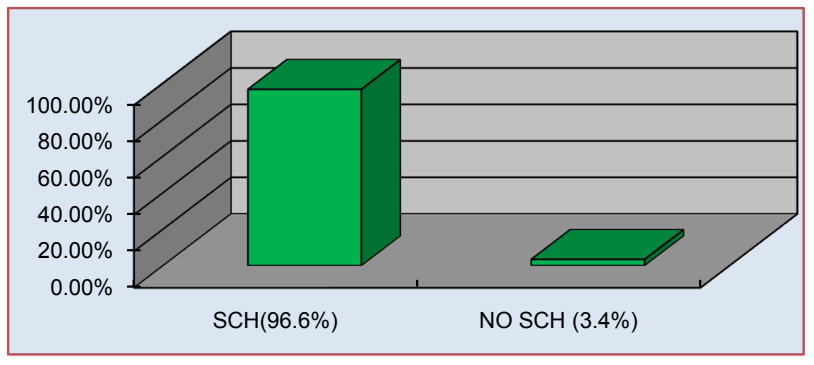

Figure 2. Students' avoiding studies while at home, Source: Author's Design using stats from GSS (GSS, 2020).

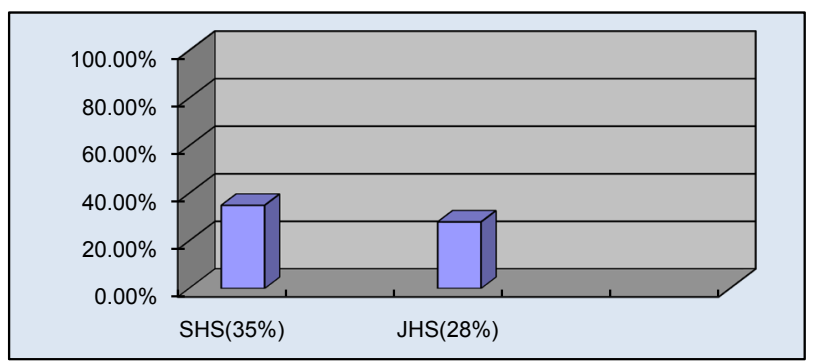

Figure 3. Students' avoiding studies while at home, Source: Author's Design using stats from GSS (GSS, 2020).

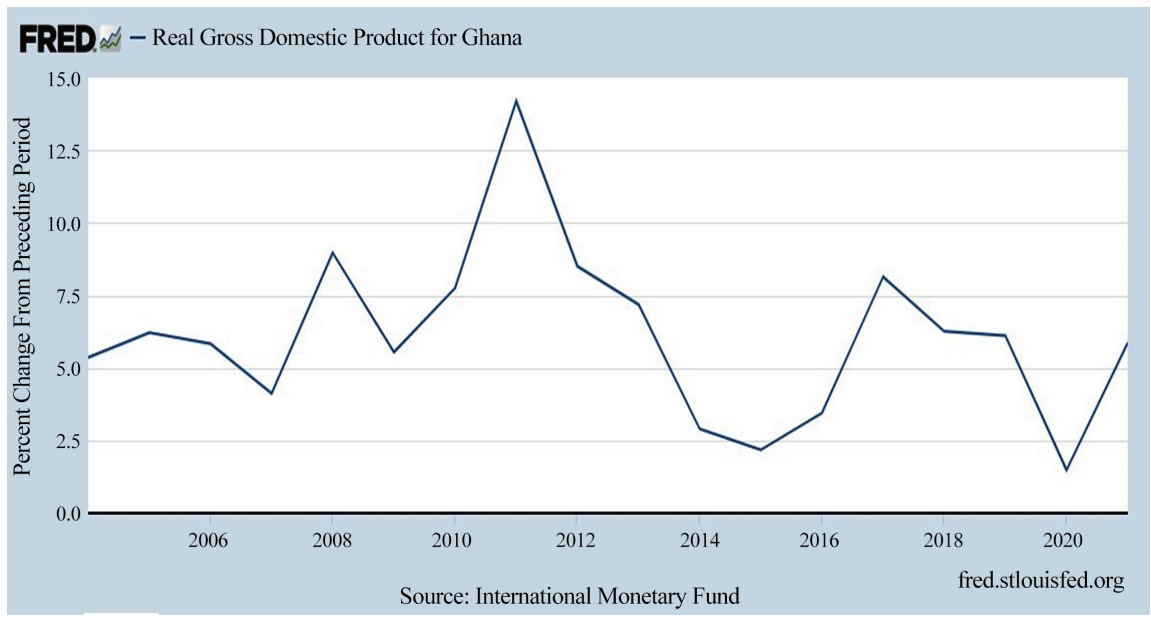

Figure 4. Real gross domestic product for Ghana. Source: International Monetary Fund (IMF; Fred.stlouisfed.Org).

\section{Discussion}

Upon viewing the COVID-19 related issues and its impact on the household consumption as well as the economic development in the region, the study investigates the post COVID-19 issues with keen interest in what happens next when the restrictions are lifted and try to answer the question about the Ghanaian household consumption, Where to here?

Where to from here? Inadequate health care facilities and workers fighting at the frontline. Some of the International institutions reported that, the African continent might not be able to avoid a grave health crisis as COVID-19 spread 
among the people (The New York Times, 2020; UNECA and ATPC, 2020). The study has a different view of this report. There is no argument that, the African countries especially Ghana, health facilities are not sufficient to combat this global canker. However, there is hope that the African continent will be the least affected continent in terms of death after this COVID-19. Because most of the African governments gained experience from the prevention measures already implemented in other countries to curb the disease. Moreover, severe measures have been laid down in these African countries even though they are not very favorable to people's freedom, but it is the normal life now. Furthermore, the continent weather help reduces the contagion, scientists made mention that the virus strength of spreading is heavily reduced in warmer-sunny weather and most of the continent weather is warm. In addition, the developed countries are striving day and night to develop a vaccine. Hopefully, the vaccine would have been developed before it gets to the grave life-threatening of Ghanaians and African regions as a whole. And to solve the health facilities inadequacy, the government is providing more Personal Protective Equipment (PPE) such as masks, gowns, gloves, and the like to health workers and further enhance the health and research facilities to prevent and withstand future pandemics.

Where to from here? Household consumption patterns uncertainties; The government of Ghana, through the financial institutions has invested and/or giving financial support to the individual households to sustain them during and after the pandemic. This approach will stabilize their food security (Gakpo, 2020). Moreover, one major key item we discovered during these uncertainties is our ability to preserve food, especially the perishable ones. Now staple foods can be stored for a long time and non-staple food such as vegetables, fruits and the like can be preserved in a way that cannot be decay easily. Also, the government continues to create Strategic Supply Reserves spreading it across the entire country with the purpose of reducing future consumption uncertainties (Awuah, 2020).

Where to from here? Another major problem is the difficulty in the food supply chain both domestic and international. Previously, the service distribution of items such as food, farming, and consumption materials were doing okay before the pandemic. Now, household looks for new market within the country as well as the neighboring countries for the consumption of products. When the restrictions are lifted, leaders of the various farming and consumption associations will bring out innovative ideas to motivate farmers in production (Larue, 2020). Furthermore, the government must put down strategies to benefit the major stakeholders in the country especially the agricultural household consumption sector. This includes the Ghana Chamber of Agribusiness, the Peasant Farmers Association etc., with the objective of fast-tracking to agricultural inputs (Awuah, 2020) which will indirectly enhance household consumption.

Where to from here? Peoples' who already enjoy the school feeding program were already undernourished (WFP, FAO \& UNICEF, 2020). The World Bank, (World Bank, 2020a) issues a leap of hope to assist developing countries in their 
responses to the fight against COVID-19. This will provide the platform and enable the efficient and effective implementation of the school feeding program with positive nutritious certainty. Furthermore, the government has put in enough finance to support the project, increasing consumption and making it more balanced diet oriented.

Where to from here? Many people's patience has worn out with the continued lockdown and hope for normal activities (Larue, 2020). With no buying and selling of consumable goods at the physical market, students staying home, workers doing their work from home, no morning park and/or scenery walking as a result of this pandemic have made many people exhausted. Further forcing them to redefine their daily routine while feeling slothful. That notwithstanding, there is hope for the economic benefit and comfortable aftermaths COVID-19. The increased number of online buying might maintain after the lockdowns which will enhance the economy of the country. Many now appreciate indoor exercises in the garden while thinning out weeds as well in the garden, leading to relaxation and improvement of health. Furthermore, there have been more teachings on the efficient utilization of time whiles on lockdown, continuing practice aftermaths of these teachings such as maintaining a consistent sleeping cycle, applying meditation techniques to release stress, and above all, eating well will improve the immune system in a long run.

From Table 2; the number of active cases has started coming down with a

Table 2. Summary of recoveries by region, March-August 27, 2020.

\begin{tabular}{ccccc}
\hline Region & Cases & Recovered/Discharged & \% Recovered/Discharged. & Active Cases \\
\hline Ahafo & 507 & 481 & 94.9 & 26 \\
Ashanti & 10,837 & 10,487 & 96.8 & 256 \\
Bono & 511 & 480 & 93.9 & 31 \\
Bono East & 763 & 711 & 93.2 & 41 \\
Central & 1870 & 1752 & 93.7 & 104 \\
Eastern & 2289 & 2032 & 88.8 & 238 \\
Greater Accra & 21,984 & 21,558 & 98.1 & 324 \\
North East & 19 & 18 & 94.7 & 0 \\
Northern & 528 & 496 & 93.9 & 21 \\
Oti & 234 & 207 & 88.5 & 25 \\
Savannah & 62 & 61 & 98.4 & 0 \\
Upper East & 282 & 279 & 98.9 & 0 \\
Upper West & 88 & 85 & 96.6 & 0 \\
Volta & 659 & 626 & 95.0 & 22 \\
Western & 2953 & 2908 & 98.5 & 41 \\
Western North & 619 & 596 & 96.3 & 23 \\
Total & 44205 & 42777 & 96.8 & 1152 \\
\hline
\end{tabular}

Source: Ghana Health Service (https://www.ghanahealthservice.org/covid19/latest.php\#). 
favorable percentage of recovery/discharge as at late August, 2020. Table 2 further indicates each region recovery rate, and this has encouraged the government to ease the restrictions with the purpose of reviving the economy, and the other sectors of development.

\section{Conclusion}

To conclude, the recuperation of the economy, household's consumption, etc. in the region will not be easy as the intervention tactics from both the private and public institutions have difference forms of incentives towards the households which in the long run may not be enough to efficiently stabilize the economy. Moreover, the government promised to improve the livelihood of the people during and after the pandemic by continuing distribution of the stimulus packages to the households, providing platforms for small businesses to obtain loans, tax mitigation for institutions, and make information on agricultural, food-related trade measures, production, consumption rate available in real-time so that it reduces panic buying and makes producers, consumers, and traders make well-versed decisions. However, households to some extent continue to look for alternative solutions for their consumption and food security, in case there is a resurgence and/or future pandemic in the country.

\section{Acknowledgements}

We thank the Almighty God for his goodness towards our lives and the preparation of this paper. Our appreciation goes to the website providers of which we obtained the data, and all those who contributed with ideas, and materials.

\section{Conflicts of Interest}

The authors declare no conflicts of interest regarding the publication of this paper.

\section{References}

Awuah, S. (2020). Oped: Ghana COVID-19-Facing Up to Food Supply Chain Problems. Farmers Review-Africa.

http://www.farmersreviewafrica.com/covid-19/2020/05/05/oped-ghana-during-covid-1 9-facing-up-to-food-supply-chain-problems

B\&FT Online (2020). Coronavirus: Extend Assistance to the Country's Food Producers to Avert a Calamity.

https://www.ghanaweb.com/GhanaHomePage/business/Coronavirus-Extend-assistanc e-to-the-country-s-food-producers-to-avert-a-calamity-969763

European Commission (2020). Coronavirus Response. Brussels. https://ec.europa.eu/transport/coronavirus-response_en?modes $=3849 \&$ category=3799

FAO (2020a). Guidelines to Mitigate the Impact of COVID-19 Pandemic on Livestock Production and Animal Health. Rome.

FAO (2020b). COVID-19 Global Economic Recession: Avoiding Hunger Must Be at the Center of the Economic Stimulus. Rome. 
FAO (2020c). Responding to the Impact of the COVID-19 Outbreak on Food Value Chains through Efficient Logistics. Rome.

FAO (2020d). Adjusting Business Models to Sustain Agri-Food Enterprises during COVID-19. Rome.

FAO (2020e). Coronavirus Disease 2019 (COVID-19). Addressing the Impacts of COVID-19 in Food Crises: April-December 2020, May Update, FAO's Component of the Global COVID-19 Humanitarian Response Plan. Rome.

FAO (2020f). Mitigating Risks to Food Systems during COVID-19: Reducing Food Loss and Waste. Rome.

FAO (2020g). Coronavirus Disease 2019 (COVID-19). Addressing the Impacts of COVID-19 in Food Crises: April-December 2020, May Update, FAO's Component of the Global COVID-19 Humanitarian Response Plan. Rome.

FAO (2020h). Policy Responses to Keep Input Markets Flowing in Times of COVID-19. Rome.

Gakpo, O. J. (2020). African Governments Mobilize to Keep People Fed during COVID-19 Lockdowns.

https://allianceforscience.cornell.edu/blog/2020/04/african-governments-mobilize-to-k eep-people-fed-during-covid-19-lockdowns

Ghana Statistical Service (GSS) (2020). More than 22 Million Ghanaians Affected by Reduction in Household Income-Survey.

https://www.businessghana.com/site/news/business/219231/More-than-22-million-Gh anaians-affected-by-reduction-in-household-income-Survey

Gray, R. S. (2020). Agriculture, Transportation, and the COVID-19 Crisis. Canadian Journal of Agricultural Economics, 68, 239-243. https://doi.org/10.1111/cjag.12235

International Monetary Fund (IMF) (2020). Real Gross Domestic Product for Ghana Product for Ghana [GHANGDPRPCPPPT]. FRED, Federal Reserve Bank of St. Louis. https://fred.stlouisfed.org/series/GHANGDPRPCPPPT

Senahoun, J. (2020). Rising from a Crisis-A More Self-Reliant Africa after Coronavirus? https://www.ghanaweb.com/GhanaHomePage/features/Rising-from-a-crisis-A-more-s elf-reliant-Africa-after-coronavirus-970093

Adade, J.-R. (2020). Govt Must Provide Free Hot Meals to JHS Three Pupils. Winneba: Dept of Psychology \& Education, University of Education.

https://www.ghanaweb.com/GhanaHomePage/features/Govt-must-provide-freee-hotmeals-to-JHS-three-pupils-983797

Laborde, D., Martin, W., Swinnen, J., \& Vos, R. (2020). COVID-19 Risks to Global Security. Science, 369, 500-502. https://science.sciencemag.org/content/369/6503/500 https://doi.org/10.1126/science.abc4765

Larue, B. (2020). Labor Issues and COVID-19. Canadian Journal of Agricultural Economics, 68, 231-237. https://doi.org/10.1111/cjag.12233

Leila, S. K. (2020). An Appreciation to Farmers: The Silent Heroes \& Heroines in the Fight against Coronavirus. Regional News.

https://www.ghanaweb.com/GhanaHomePage/regional/An-appreciation-to-Farmers-T he-silent-heroes-heroines-in-the-fight-against-coronavirus-976405

Li, Q., Guan, X., Wu, P. et al. (2020). Early Transmission Dynamics in Wuhan, China, of Novel Coronavirus Infected Pneumonia. New England Journal of Medicine, 382, 1199-1207.

The New York Times (2020). Africa Braces for Coronavirus, But Slowly. New York. 
https://www.worldbank.org/

United Nations Economic Commission for Africa (UNECA) and African Trade Policy Centre (ATPC) (2020). Trade Policies for Africa to Tackle Covid-19. Addis Ababa: UNECA. https://www.uneca.org/

WFP, FAO, \& UNICEF (2020). Interim Guidance Note: Mitigating the Effects of the COVID-19 Pandemic on Food and Nutrition of Schoolchildren. Rome.

William, A. K. (2020). The COVID-19 Pandemic and Agriculture: Short- and Long-Run Implications for International Trade Relations. Wiley Special Issue Article.

World Bank (2020a). How the World Bank Group Is Helping Countries with COVID-19 (Coronavirus). Washington DC. https://www.nytimes.com/

World Bank (2020b). Global Economic Prospects, June 2020. Washington DC: World Bank. https://openknowledge.worldbank.org/handle/10986/33748

https://data.worldbank.org/country/ghana?view=chart

World Health Organization (WHO) (2020). Modes of Transmission of Virus Causing COVID-19: Implications for IPC Precaution Recommendations. Geneva.

https://www.who.int/

World Health Organization (WHO), Food and Agriculture Organization (FAO), \& World Trade Organization (WTO) (2020). Tedros Adhanom Ghebreyesus, QU Dongyu and Roberto Azevedo, Directors-General of WHO, FAO and WTO. http://www.fao.org/news/story/en/item/1268719/icode

Kerr, W. A. (2020). The COVID-19 Pandemic and Agriculture: Short- and Long-Run Implications for International Trade Relations. Canadian Journal of Agricultural Economics, 68, 225-229.

Masters, W. (2020). COVID-19 Impacts on Agriculture, Food, and Nutrition. Medford, MA: Tuft University.

https://econofact.org/covid-19-impacts-on-agriculture-food-and-nutrition 